\title{
Aerosol optical extinction during the Front Range Air Pollution and Photochemistry Éxperiment (FRAPPÉ) 2014 summertime field campaign, Colorado, USA
}

\author{
Justin H. Dingle ${ }^{1}$, Kennedy Vu ${ }^{1}$, Roya Bahreini ${ }^{1,2}$, Eric C. Apel ${ }^{3}$, Teresa L. Campos ${ }^{3}$, Frank Flocke ${ }^{3}$, Alan Fried ${ }^{4}$, \\ Scott Herndon ${ }^{5}$, Alan J. Hills ${ }^{3}$, Rebecca S. Hornbrook ${ }^{3}$, Greg Huey ${ }^{6}$, Lisa Kaser ${ }^{3}$, Denise D. Montzka ${ }^{3}$, \\ John B. Nowak ${ }^{5}$, Mike Reeves ${ }^{3}$, Dirk Richter ${ }^{4}$, Joseph R. Roscioli ${ }^{5}$, Stephen Shertz ${ }^{3}$, Meghan Stell ${ }^{3}$, David Tanner ${ }^{6}$, \\ Geoff Tyndall $^{3}$, James Walega ${ }^{4}$, Petter Weibring ${ }^{4}$, and Andrew Weinheimer ${ }^{3}$ \\ ${ }^{1}$ Environmental Toxicology Graduate Program, University of California, Riverside, CA 92521, USA \\ ${ }^{2}$ Department of Environmental Sciences, University of California, Riverside, CA 92521, USA \\ ${ }^{3}$ National Center for Atmospheric Research, Boulder, CO 80301, USA \\ ${ }^{4}$ Institute for Arctic and Alpine Research, University of Colorado, Boulder, CO 80303, USA \\ ${ }^{5}$ Aerodyne Research, Inc., Billerica, MA 01821, USA \\ ${ }^{6}$ Department of Earth and Atmospheric Sciences, Georgia Institute of Technology, Atlanta, GA 30033, USA
}

Correspondence to: Roya Bahreini (roya.bahreini@ucr.edu)

Received: 11 March 2016 - Published in Atmos. Chem. Phys. Discuss.: 14 April 2016

Revised: 9 August 2016 - Accepted: 21 August 2016 - Published: 12 September 2016

\begin{abstract}
Summertime aerosol optical extinction $\left(\beta_{\text {ext }}\right)$ was measured in the Colorado Front Range and Denver metropolitan area as part of the Front Range Air Pollution and Photochemistry Éxperiment (FRAPPÉ) campaign during July-August 2014. An Aerodyne cavity attenuated phase shift particle light extinction monitor $\left(\right.$ CAPS-PM $\left.M_{\mathrm{ex}}\right)$ was deployed to measure $\beta_{\text {ext }}$ (at average relative humidity of $20 \pm 7 \%$ ) of submicron aerosols at $\lambda=632 \mathrm{~nm}$ at $1 \mathrm{~Hz}$. Data from a suite of gas-phase instrumentation were used to interpret $\beta_{\text {ext }}$ behavior in various categories of air masses and sources. Extinction enhancement ratios relative to $\mathrm{CO}$ $\left(\Delta \beta_{\text {ext }} / \Delta \mathrm{CO}\right)$ were higher in aged urban air masses compared to fresh air masses by $\sim 50 \%$. The resulting increase in $\Delta \beta_{\text {ext }} / \Delta \mathrm{CO}$ for highly aged air masses was accompanied by formation of secondary organic aerosols (SOAs). In addition, the impacts of aerosol composition on $\beta_{\text {ext }}$ in air masses under the influence of urban, natural oil and gas operations $(\mathrm{O} \& \mathrm{G})$, and agriculture and livestock operations were evaluated. Estimated non-refractory mass extinction efficiency (MEE) values for different air mass types ranged from 1.51 to $2.27 \mathrm{~m}^{2} \mathrm{~g}^{-1}$, with the minimum and maximum values observed in urban and agriculture-influenced air masses, respectively. The mass distribution for organic, nitrate, and sul-
\end{abstract}

fate aerosols presented distinct profiles in different air mass types. During 11-12 August, regional influence of a biomass burning event was observed, increasing the background $\beta_{\text {ext }}$ and estimated MEE values in the Front Range.

\section{Introduction}

The aerosol optical extinction coefficient $\left(\beta_{\text {ext }}\right)$ represents the attenuation of light due to aerosol absorption and scattering of solar radiation. For a population of aerosol particles, $\beta_{\text {ext }}$ depends on aerosol size, composition, particle number concentration, shape, and morphology (Bohren and Huffman, 1998). Atmospheric aerosols have important implications on climate. They modify the Earth's radiative energy budget directly through absorption and scattering of light and indirectly through changing cloud characteristics (e.g., cloud droplet number concentration, cloud droplet size, cloud reflectivity, or lifetime) (Ramanathan et al., 2001; Seinfeld and Pandis, 2006; Langridge et al., 2011). In addition, aerosols with diameters between 0.1 to $1 \mu \mathrm{m}$ are the main contributors to visibility degradation in anthropogenically polluted areas and on regional scales due to their direct interactions 
with solar radiation (Malm, 1989; Hobbs, 2000; Ying et al., 2004). For example, it has been observed that the important anthropogenic contributors to light scattering in the Colorado Rocky Mountains are particulate matter from the urban emissions (Levin et al., 2009). The Denver metropolitan area has also experienced seasonal air pollution and visibility degradation in the past. The wintertime pollution in Denver when trapped closer to the surface due to the low inversion layer causes a greyish-brown cloud referenced to as the "Denver brown cloud." The composition of the Denver brown cloud and contribution of different chemical species to the observed $\beta_{\text {ext }}$ during the wintertime have been investigated in the 1970s to late 1980s (Groblicki et al., 1981; Wolff et al., 1981; Neff, 1997). These studies concluded that, among all the measured aerosol species, elemental carbon, ammonium sulfate, and ammonium nitrate contributed the most $(37.7,20.2$, and $17.2 \%$, respectively) to wintertime optical extinction in the visible range. Previous measurements of summertime particle composition in the Colorado Front Range were conducted during the northern Front Range Air Quality Study (NFRAQS) between 17 July and 31 August 1996 at several urban and rural sites. The major components of $\mathrm{PM}_{2.5}$ mass were identified to be carbonaceous and inorganic aerosols, with carbonaceous aerosols contributing about $46 \%$ of $\mathrm{PM}_{2.5}$ mass. The $24 \mathrm{~h}$ average measurements of $\mathrm{PM}_{2.5}$ organic carbon, nitrate, and sulfate particles were observed to be $4.2,0.9-1.2 \mu \mathrm{g} \mathrm{m}^{-3}$, and 1.41.5, respectively (Watson et al., 1998). In response to the wintertime haze episodes observed in the region, the State of Colorado has implemented a visibility standard based on total optical extinction of $76 \mathrm{Mm}^{-1}$ at $550 \mathrm{~nm}$, averaged during a $4 \mathrm{~h}$ period when ambient relative humidity $(\mathrm{RH})$ is less than $70 \%$ (Ely et al., 1993). Total optical extinction measurements are provided by the Colorado Department of Public Health and Environment's transmissometer installed in downtown Denver. The average total extinction values of August 2001-2014, ranging from 40 to $80 \mathrm{Mm}^{-1}$, reveal no significant trend in summertime extinction and visibility in the region since 2001.

The meteorological influence on air quality and visibility in the Front Range can also be important (e.g., Vu et al., 2016). Typically during the day, easterly upslope flow transports emissions from local sources westward, while during the night the flow reverses and downslope drainage flow through Platte River valley sets in. Occasionally, a synoptic scale cyclone, called the Denver cyclone, is established when drainage flow of air masses is prevented due to propagation of a vortex that develops east of the Rocky Mountains, contributing to transport and mixing of air masses in a cyclonic flow pattern (Crook et al., 1990; Reddy et al., 1995).

With a twofold increase in natural-resource extraction wells since 2005 to about 24000 active oil and natural gas (O\&G) production wells in 2012, northeastern Colorado has experienced extensive fossil fuel production within the past decade (Scamehorn, 2002; Pétron et al., 2014). This includes increases in fossil fuel production from coal bed methane, tight sand and shale natural gas, shale oil, and the associated gases. The emissions from these processes have several environmental impacts, such as greenhouse emissions of methane and emissions of non-methane hydrocarbons, that impair air quality. Emissions from diesel trucks, drilling rigs, power generators, phase separators, dehydrators, storage tanks, compressors, and pipes used in O\&G operations also contribute to the regional burden of volatile organic compounds (VOCs), nitrogen oxides, and particulate matter (i.e., black carbon and primary organic carbon) (Gilman et al., 2013). One of the major air quality issues the Colorado Front Range faces is the exceedance of the $8 \mathrm{~h} \mathrm{Na}$ tional Ambient Air Quality Standard (NAAQS) standard for ozone (75 ppbv) during the summertime. In 2007, the Denver metropolitan area and the northern parts of the Colorado Front Range were classified as nonattainment areas due to the summertime elevated levels of ozone (www.colorado.gov/ cdphe/attainment). Summertime impacts of O\&G emissions on the formation of secondary pollutants and visibility reduction in the Front Range have not been explored previously. In addition to local point and area sources in the Front Range, biomass burning (BB) emissions from wildfires in the region may also act as a source of aerosols, contributing to regional haze (Park et al., 2003).

During July-August 2014, airborne measurements were conducted over the Colorado Front Range as part of the Front Range Air Pollution and Photochemistry Éxperiment (FRAPPÉ) to characterize the influence of sources, photochemical processing, and transport on atmospheric gaseous and aerosol pollutants in the area. This paper will discuss the role of local aerosol sources in the Front Range and regional wildfires on aerosol optical extinction in the absence of the Denver cyclone by investigating chemical and optical properties of aerosols in different air masses.

\section{Measurements}

\subsection{FRAPPÉ field campaign}

In situ measurements were conducted aboard the National Science Foundation/National Center for Atmospheric Research (NSF/NCAR) C-130 aircraft during 20 July-18 August 2014. Flight tracks of the C-130, color coded with different trace gases, are presented in Fig. 1a-c. In the current analysis, airborne data were limited to those obtained only in the boundary layer of the Colorado Front Range (i.e., altitudes below $2500 \mathrm{~m}$ above sea level (a.s.1.) east of the foothills and below $5500 \mathrm{~m}$ a.s.l. with easterly winds over the foothills and the Continental Divide) to capture the influence of local sources such as power plants, O\&G, agriculture, livestock, and urban emissions. Occasionally, when air masses with the mountain-valley circulation patterns were sampled, 

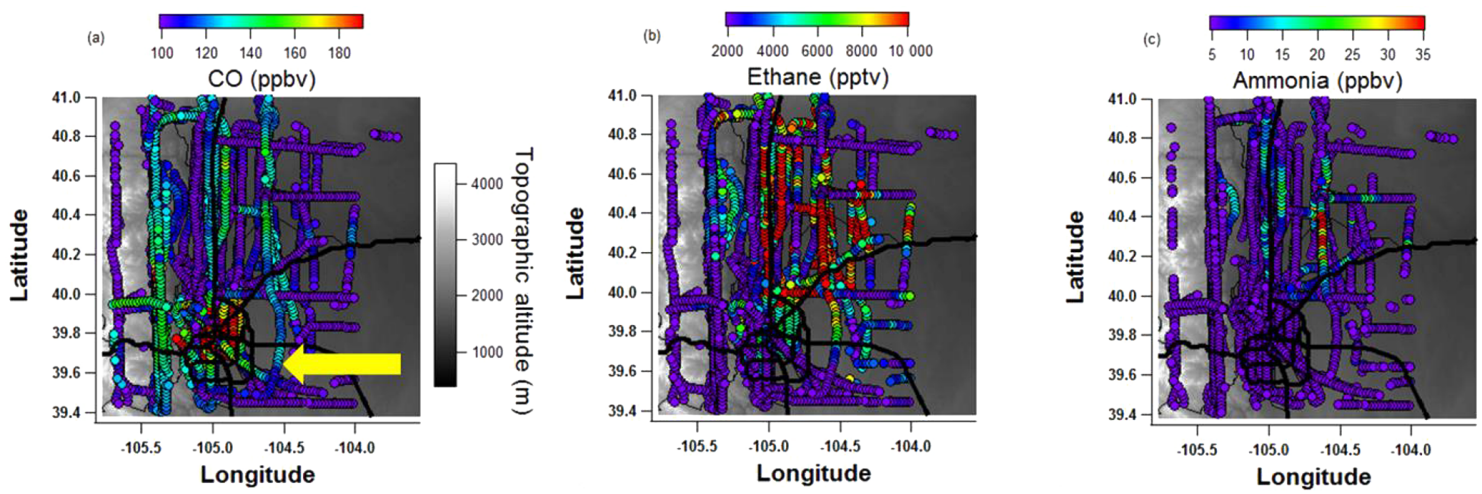

Figure 1. C-130 flight tracks in the Colorado Front Range, color coded with observed mixing ratios of (a) CO, (b) ethane, and (c) ammonia. The yellow arrow indicates the Denver metropolitan area. To the west of the Denver metropolitan area are the Rocky Mountain foothills depicted by the topographic color scheme.

data from higher altitudes $(<4000 \mathrm{~m}$ a.s.l. $)$ over the Denver metropolitan area were also considered.

\subsection{Instrumentation and methodology}

The NSF/NCAR C-130 aircraft carried an extensive collection of instruments for the characterization of the diverse atmospheric pollutants in the Colorado Front Range. The relevant instrumentations used in the current analysis are described below. (The data produced by these instruments are available at http://www-air.larc.nasa.gov/cgi-bin/ ArcView/discover-aq.co-2014?C130=1).

The extinction coefficient $\left(\beta_{\text {ext }}\right)$ at $632 \mathrm{~nm}$ was measured using a cavity attenuated phase shift particle light extinction monitor (CAPS-PM $\mathrm{ex}$ ) (Aerodyne Research Inc., Billerica, MA). The CAPS-PM $\mathrm{ex}_{\mathrm{x}}$ utilizes high-reflectivity mirrors at two ends of a $26 \mathrm{~cm}$ long, near-confocal cavity. Within the optical cell cavity, the highly reflective mirrors create an effective path length of approximately $2 \mathrm{~km}$. In the particlefree sampling mode, the light-emitting diode (LED) light output is directed to the first mirror, while a small fraction passes through the second mirror to the photodiode detector, producing a slightly distorted waveform of the square-wave modulated by the LED, whereas in the aerosol sampling mode the detector detects a greater distorted waveform, characterized by a phase shift. The vacuum photodiode, which is located behind the second reflective mirror, detects and measures that phase shift when the square wave becomes distorted due to interactions with sampled air under a relatively long effective pathlength. The observed phase shift is then related to aerosol $\beta_{\mathrm{ext}}$ as follows:

$\beta_{\mathrm{ext}}=\left(\cot \theta-\cot \theta_{o}\right) \cdot(2 \pi f / c)$,

where $\cot \theta_{o}$ is the phase shift from the particle-free sampling mode, $\cot \theta$ is the phase shift during the aerosol sampling mode, $f$ is the frequency, and $c$ is the speed of light. The estimated uncertainty in $\beta_{\text {ext }}$ is $10 \%$, while the $3 \sigma$ detection limit for $1 \mathrm{~s}$ data under the conditions of particle-free air encountered during FRAPPÉ was $\sim 1.5 \mathrm{Mm}^{-1}$ (Massoli et al., 2010; Petzold et al., 2013). Measurements of the baseline were conducted through the system's internal filter unit regularly, at $5 \mathrm{~min}$ intervals. The filter period, which lasted for $1 \mathrm{~min}$, included $10 \mathrm{~s}$ of flush time, then $40 \mathrm{~s}$ of filter sampling, followed by another $10 \mathrm{~s}$ of flush time. Although, for the majority $(72 \%)$ of the data, consecutive baseline values had shifted by less than $0.5 \mathrm{Mm}^{-1}$, baseline values were interpolated for a more accurate estimation of optical extinction. CAPS-PM $\mathrm{Px}_{\mathrm{ex}}$ data, obtained at $1 \mathrm{~Hz}$, were averaged to the aerosol mass spectrometer's averaging time of $15 \mathrm{~s}$. The measured $\beta_{\text {ext }}$ includes the combined effects of scattering and absorption of light by aerosols at $632 \mathrm{~nm}$; given relatively high single-scattering albedo values of aerosols downwind of urban environments (Langridge et al., 2012), $\beta_{\text {ext }}$ is expected to be dominated by the scattering coefficient. As discussed in Sects. 3.3 and 3.4, in urban or biomass-burning-influenced air masses, contribution of absorption by black carbon (BC) to $\beta_{\text {ext }}$ could be more significant. It is worth mentioning that anthropogenic gases such as nitrogen dioxide have minimal effect on the measured $\beta_{\text {ext }}$ at $632 \mathrm{~nm}$ since regular baseline corrections based on sampled filtered air were applied to the data. Given the average mixing ratio of $\mathrm{NO}_{2}$, the parameterization by Groblicki et al. (1981) for estimating $\mathrm{NO}_{2}$ absorption at $550 \mathrm{~nm}$, and the factor-of-10-smaller value of $\mathrm{NO}_{2}$ absorption cross section at $632 \mathrm{~nm}$ compared to $550 \mathrm{~nm}$ (Schneider et al., 1987), we estimated the average contribution of $\mathrm{NO}_{2}$ absorption at $632 \mathrm{~nm}$ to be $\sim 0.1 \mathrm{Mm}^{-1}$, indicating a minor contribution to total extinction at $632 \mathrm{~nm}$.

The CAPS-PM $\mathrm{ex}_{\mathrm{ex}}$ shared a common inlet with a compact aerosol mass spectrometer (mAMS; Aerodyne Inc., Billerica, MA) coupled with a time-of-flight (TOFwerk, Thun, Switzerland) detector to measure particle mass distribution and non-refractory submicron aerosol composition (NR$\mathrm{PM}_{1}$ ) of organics, nitrate, sulfate, chloride, and ammonium. The mAMS inlet was characterized to have a $50 \%$ transmission of $\sim 800 \mathrm{~nm}$ (physical diameter) particles. Aerosol 
concentrations from the mAMS were corrected for vaporizer bounce using composition-dependent collection efficiencies (Middlebrook et al., 2012). The estimated uncertainty for all aerosol species is $\sim 30 \%$ (Bahreini et al., 2009). Both instruments sampled particles through a secondary diffuser mounted inside a NCAR HIAPER (High-performance Instrumented Airborne Platform for Environmental Research) modular inlet (HIMIL), mounted facing forward, under the C-130 aircraft. Given the total flow rate within the inlet and assuming particle density of $1500 \mathrm{~kg} \mathrm{~m}^{-3}$, ambient temperature of $20^{\circ} \mathrm{C}$, and ambient pressure of $70 \mathrm{KPa}, 2 \mu \mathrm{m}$ particles were estimated to be transmitted by $50 \%$, making the inlet nominally a $\mathrm{PM}_{2}$ inlet. Residence time in the inlet was estimated to be $\sim 0.56 \mathrm{~s}$. Ambient aerosol size distributions were measured aboard the C-130 by a Passive Cavity Aerosol Spectrometer Probe (PCASP). Estimated extinction values using Mie calculations with a nominal refractive index of 1.5 and the measured PCASP size distributions indicated that particles smaller than $800 \mathrm{~nm}$ captured $>92 \%$ of $\mathrm{PM}_{2}$ extinction values, confirming that the majority of the extinction signal originated from aerosols in the size range of the mAMS. We note that the calculated extinction coefficients were not highly sensitive to the choice of refractive index; only a $4 \%$ decrease in the slope of scattering from $\mathrm{PM}_{0.8} \mathrm{vs}$. $\mathrm{PM}_{2}$ was observed by increasing the refractive index from 1.48 to 1.52 .

Based on the ambient $\mathrm{RH}$ and temperature and the temperature within the CAPS-PM ${ }_{\mathrm{ex}}$ extinction cell, and assuming that aerosols had equilibrated to the conditions within the measurement cell, the CAPS-PM ${ }_{\mathrm{ex}}$ measurements during the flights discussed here represent extinction values at an average RH of $20 \pm 7 \%$ (range of 15-30\%). Additionally, $\beta_{\text {ext }}$ values were normalized for standard temperature and pressure ( $273 \mathrm{~K}$ and $1 \mathrm{~atm})$ conditions.

The relationship between the primarily emitted nitrogen oxides $\left(\mathrm{NO}_{x}\right)$ and the higher oxidized species of nitrogen captures the transformation of $\mathrm{NO}_{x}$ in the atmosphere upon aging (Kleinman et al., 2007; Langridge et al., 2012). Thus, measurements of nitric oxide $(\mathrm{NO})$, nitrogen dioxide $\left(\mathrm{NO}_{2}\right)$, nitric acid $\left(\mathrm{HNO}_{3}\right)$, particulate phase nitrate $\left(\mathrm{NO}_{3}^{-}\right)$, alkyl nitrates (ANs), peroxy acetyl nitrate (PAN), and peroxy propionyl nitrate $(\mathrm{PPN})$ were used to calculate the ratio of primary nitrogen oxides $\left(\mathrm{NO}_{x}=\mathrm{NO}+\mathrm{NO}_{2}\right)$ to $\mathrm{NO}_{y}\left(\mathrm{NO}_{y}\right.$ $=\mathrm{NO}_{x}+\mathrm{HNO}_{3}+\mathrm{NO}_{3}^{-}+\mathrm{ANs}+\mathrm{PAN}+\mathrm{PPN}$ ) in order to track the extent of photochemical aging in an air mass with nonzero emissions of $\mathrm{NO}_{x}$ (Kleinman et al., 2007; DeCarlo et al., 2010). A ratio that yields a value close to 1 represents air masses that are relatively fresh, whereas a ratio closer to 0 represents more-aged air masses. $\mathrm{NO}$ and $\mathrm{NO}_{2}$ were measured using the NCAR two-channel chemiluminescence instrument (Ridley and Grahek, 1990). A chemical ionization mass spectrometer (CIMS) coupled with a quadrupole detector was operated to measure $\mathrm{HNO}_{3}$, using $\mathrm{SF}_{5}^{-}$as the reagent ion (Huey et al., 1998; Huey, 2007). ANs were measured using thermal-dissociation laser-induced fluorescence
(TD-LIF) (Thornton et al., 2000; Day et al., 2002). PAN and PPN species were measured using the CIMS Instrument by Georgia Tech and NCAR (PAN-CIGAR; Slusher et al., 2004; Zheng et al., 2011), with $\mathrm{I}^{-}$as the reagent ion.

The impacts of different pollution sources on sampled air masses were characterized by considering several auxiliary gas-phase tracers. Carbon monoxide, the tracer for combustion emissions, was measured by vacuum ultra-violet fluorescence with the estimated uncertainty of $3 \%$ (Gerbig et al., 1999). Ethane $\left(\mathrm{C}_{2} \mathrm{H}_{6}\right)$, used to identify influence of O\&G emissions, was measured using the Compact Atmospheric Multispecies Spectrometer (CAMS), employing infrared spectrometry (Richter et al., 2015). The Aerodyne dual quantum cascade trace gas monitor for ammonia $\left(\mathrm{NH}_{3}\right)$ equipped with a mid-infrared absorption spectrometer was used to identify emissions of agriculture and livestock operations (Ellis et al., 2010). The influence of biomass burning was identified using the measurements of hydrogen cyanide from the NCAR Trace Organic Gas Analyzer (TOGA), a fast gas chromatograph coupled with a quadrupole mass spectrometer (GC-MS) set to selected ion-monitoring mode for quantification (Apel et al., 2015) and acetonitrile $\left(\mathrm{CH}_{3} \mathrm{CN}\right)$ by proton-transfer reaction mass spectrometry (PTR-MS), a high-sensitivity instrument with fast time response that employs a quadrupole mass spectrometer to measure volatile organic compounds (de Gouw and Warneke, 2007; Karl et al., 2009). A Passive Cavity Aerosol Spectrometer Probe (PCASP) was available as the only instrument to measure ambient aerosol size distributions in the size range of 0.1$3 \mu \mathrm{m}$ (Rosenberg et al., 2012).

\section{Results and discussion}

\subsection{Urban aerosol optical extinction characterization in different photochemical aging regimes}

$\mathrm{NO}_{x} / \mathrm{NO}_{y}$ ratios were observed to be highest over the city, representing freshly emitted plumes from vehicular traffic (Fig. S1 in the Supplement). Away from the city center, $\mathrm{NO}_{x} / \mathrm{NO}_{y}$ values decrease, representing the relative evolution of fresh air masses containing $\mathrm{NO}_{x}$. Figure 2 shows the scatterplot of $\beta_{\text {ext }}$ vs. $\mathrm{CO}$, color coded with the $\mathrm{NO}_{x} / \mathrm{NO}_{y}$ ratio, on 2-3, 7-8, 15-16, and 18 August (i.e., excluding days with the influences of the Denver cyclone and biomass burning events). Measurements here focused on air masses impacted by urban sources only, as defined by enhancement of $\mathrm{CO}$ over the background ( $105 \mathrm{ppbv}$, as defined by the mode in the frequency distribution of $\mathrm{CO}$ in the Front Range boundary layer) while $\Delta \mathrm{C}_{2} \mathrm{H}_{6} / \Delta \mathrm{CO}<20 \mathrm{pptv}_{\mathrm{ppbv}}{ }^{-1}$ (Warneke et al., 2007; Borbon et al., 2013). The extinction enhancement ratios $\Delta \beta_{\text {ext }} / \Delta \mathrm{CO}$ in two aging regimes, categorized by $\mathrm{NO}_{x} / \mathrm{NO}_{y}$ ratio values, were analyzed by weighted linear orthogonal distance regression (ODR) fits, with the slopes representing the enhancement ratios. In obtaining 


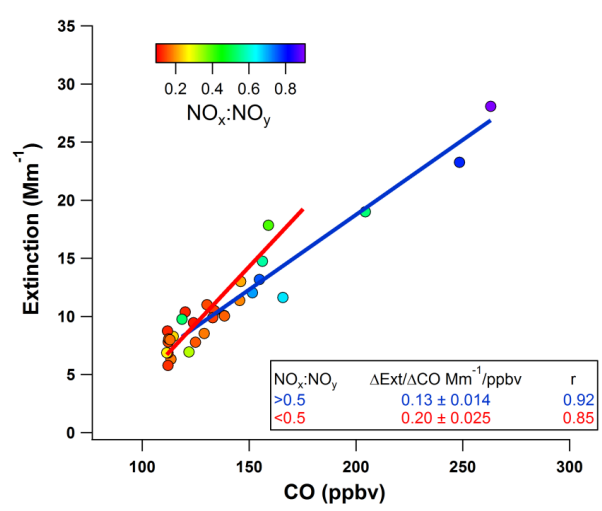

Figure 2. Orthogonal distance linear regression fits to extinction $\left(\mathrm{Mm}^{-1}\right)$ vs. CO (ppbv) for fresh (blue fit line) and aged air masses (red fit line).

these fits, weights represented standard deviations equal to the uncertainties in $\mathrm{CO}(3 \%)$ and $\beta_{\text {ext }}(10 \%)$. Uncertainties in the slope values of ODR fits throughout the manuscript represent the estimated propagated uncertainties, in this case the square root of the quadratic sum of the relative uncertainties in the ODR fit $(1 \sigma), \mathrm{CO}$ mixing ratio, and $\beta_{\text {ext }}$ coefficient. $\mathrm{NO}_{x} / \mathrm{NO}_{y}$ values of $<0.5$ and $>0.5$ represent relatively aged and fresh $\mathrm{NO}_{x}$-containing air masses, respectively. Different trends in $\Delta \beta_{\text {ext }} / \Delta \mathrm{CO}$ were seen in the two aging regimes, with a lower value of $0.13 \pm 0.014 \mathrm{Mm}^{-1} \mathrm{ppbv}^{-1}$ observed in the fresh air masses. On the other hand, the relatively aged air masses showed a higher $\Delta \beta_{\text {ext }} / \Delta \mathrm{CO}$ value of $0.20 \pm 0.025 \mathrm{Mm}^{-1} \mathrm{ppbv}^{-1}$, indicating about a $54 \%$ increase in the extinction enhancement ratio due to photochemical aging. The correlation coefficient $r$ values were 0.92 and 0.85 for relatively fresh and aged air masses, respectively. The most dominant component of the non-refractory aerosols in urban plumes was organic aerosol (OA), with a contribution of $74 \%$ of NR-PM $\mathrm{PM}_{1}$ mass. The high OA contribution combined with the observed significant increase in the enhancement ratio of $\mathrm{OA}$ to $\mathrm{CO}$ with aging (from $0.021 \pm 0.009$ to $0.11 \pm 0.01 \mu \mathrm{g} \mathrm{m}^{-3} \mathrm{ppbv}^{-1}$ ) suggests that the bulk of the aged urban aerosol mass during the daytime in the Front Range was secondary organic aerosol (SOA). Although carrying out positive matrix factorization analysis on the measured OA mass spectra during FRAPPÉ is beyond the scope of this paper, such analysis in the future would be conducive to confirming the large contribution of SOA to the measured OA. Since $\Delta \mathrm{NO}_{3}^{-} / \Delta \mathrm{CO}$ and $\Delta \mathrm{SO}_{4}^{2-} / \Delta \mathrm{CO}$ enhancement ratios did not increase with photochemical aging and demonstrated poor overall correlation coefficients $\left(r<0.35\right.$ for $\Delta \mathrm{NO}_{3}^{-} / \Delta \mathrm{CO}$ and $r<0.29$ for $\left.\Delta \mathrm{SO}_{4}^{2-} / \Delta \mathrm{CO}\right)$, the increase in the enhancement ratio of the aerosol optical extinction coefficient with $\mathrm{CO}$ was likely also driven by SOA formation.

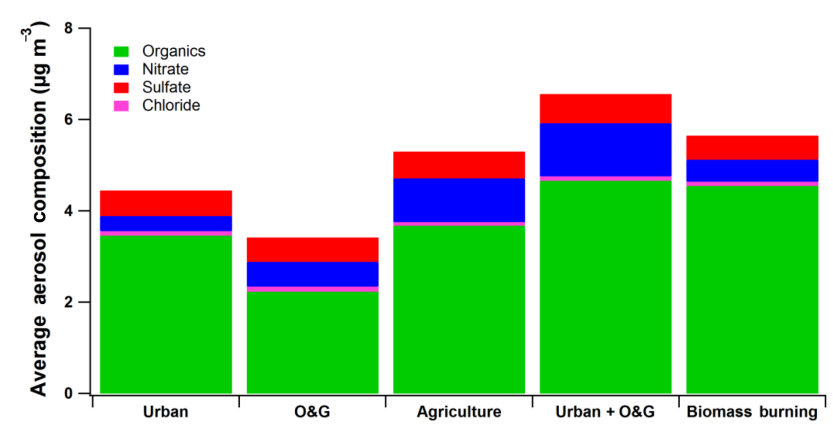

Figure 3. Average chemical composition $\left(\mu \mathrm{g} \mathrm{m}^{-3}\right)$ of nonrefractory aerosols for different air mass sources.

\subsection{Impacts of source and aerosol composition on aerosol optical extinction}

Analysis of the average composition of NR-PM $\mathrm{PM}_{1}$ in the Northern Front Range, in the absence of the Denver cyclone, revealed significantly higher concentrations of organic aerosols relative to inorganic anions in the urban and urban + O\&G-influenced air masses, with a fractional contribution of $\sim 74 \%$ (Fig. 3). On average, similar concentrations of non-refractory aerosol sulfate and chloride were observed in the different air masses, while concentration of nitrate aerosols increased by a factor of $\sim 2-3$ in agriculturally influenced air masses compared to the other air mass types with the exception of urban $+O \& G$ air masses.

Aerosol optical extinction values under the influence of different sources were further analyzed using auxiliary gasphase data. As mentioned in Sect. 3.1, urban emissions were classified by enhancement of $\mathrm{CO}$ over the background (105 ppbv, as defined by the mode in the frequency distribution of $\mathrm{CO}$ in the Front Range boundary layer) while $\Delta \mathrm{C}_{2} \mathrm{H}_{6} / \Delta \mathrm{CO}<20 \mathrm{pptv} \mathrm{ppbv}^{-1}$. O\&G and agricultural emissions were classified using enhancements of $\mathrm{C}_{2} \mathrm{H}_{6}$ over $2500 \mathrm{pptv}$ and those of ammonia over $5 \mathrm{ppbv}$, respectively, while all other tracers were at background level. A fourth air mass classification used in this analysis, urban + O\&G, was based on air masses where both urban and $O \& G$ classifications were satisfied. The background mixing ratios for each gas tracer were determined by the mode of the frequency distribution of the tracer's mixing ratio observed in each flight. The impacts of sources and aerosol composition on extinction were explored by considering correlation coefficients of linear least-squares regression fits to the scatterplots of aerosol extinction vs. the mass concentration of the three dominant aerosol species (OA, nitrate aerosols, and sulfate aerosols) in urban, O\&G-, urban + O\&G-, and agriculturally influenced air masses.

Figure 4 shows the correlation coefficient $(r)$ values of extinction vs. aerosol species mass concentration, in different air mass types as characterized above. The scatterplots of $\beta_{\text {ext }}$ vs. OA under conditions of urban, $\mathrm{O} \& \mathrm{G}$, and ur- 
ban + O\&G air masses presented correlation coefficients of $r=0.46,0.72$, and 0.46 , respectively. This observation suggests that $\mathrm{O} \& \mathrm{G}$ emissions are important for organic aerosol contribution to $\beta_{\text {ext }}$. On the other hand, in urban plumes, the correlation between $\beta_{\text {ext }}$ and OA was lower than in O\&G plumes, while, as demonstrated in Fig. 2, $\beta_{\text {ext }}$ and $\mathrm{CO}$ were strongly correlated under conditions of both fresh and aged air masses. These observations suggest that species other than OA, e.g., black carbon, that are co-emitted with $\mathrm{CO}$ are also important in driving $\beta_{\text {ext }}$ in urban air masses. The correlation between $\beta_{\text {ext }}$ vs. OA was weakest in plumes with agricultural emissions $(r=0.085)$, suggesting OA had little impact on $\beta_{\text {ext }}$ in these plumes. The correlation coefficients for $\beta_{\text {ext }}$ vs. aerosol nitrate mass were strongest under the influence of $\mathrm{O} \& \mathrm{G}$, urban $+\mathrm{O} \& \mathrm{G}$, and agriculture and livestock emissions ( $r=0.75,0.75$, and 0.90 , respectively) and weakest in the urban plumes $(r=0.18)$. Aerosol nitrate formation depends on ambient conditions (temperature and relative humidity), relative mixing ratios of nitric acid and ammonia, and aerosol composition and $\mathrm{pH}$ (Seinfeld and Pandis, 2006; Weber et al., 2016). With uniform concentrations of sulfate aerosol and small contribution of chloride and dust components to the Front Range fine aerosol mass, variability in aerosol $\mathrm{pH}$ was not expected to be high. Furthermore, there was no specific trend in temperature or relative humidity in different plume types. On the other hand, mixing ratios of ammonia were observed to be variable in the different air masses, with average values of $1.41 \pm 1.2,2.75 \pm 1.88$, $8.21 \pm 2.06$, and $5.47 \pm 1.81 \mathrm{ppbv}$ in urban, O\&G, agriculture, and urban + O\&G plumes, respectively. These observations suggest that ammonia emissions that are colocated with O\&G-related activities in the Front Range play a significant role in controlling $\beta_{\text {ext }}$ in these air masses by enhancing the partitioning of nitric acid to the condensed phase. In fact, the average aerosol inorganic nitrate fraction over total inorganic nitrate (aerosol nitrate $/\left[\mathrm{HNO}_{3}+\right.$ aerosol nitrate $]$ ) in agriculture and $\mathrm{O} \& \mathrm{G}$ plumes were $0.25 \pm 0.09$ and $0.11 \pm 0.10$, respectively, compared to $0.070 \pm 0.071$ in urban plumes. $\beta_{\text {ext }}$ was poorly correlated with sulfate aerosols in the region under the influence of all sources $(r=0.30,0.37,0.07,0.23$ for urban, O\&G, agriculture, and urban $+\mathrm{O} \& \mathrm{G}$, respectively), suggesting a low impact of sulfate aerosol and its precursors on $\beta_{\text {ext }}$ in the region.

Due to the higher hygroscopicity of inorganic salts compared to organics, contribution of sulfate and nitrate aerosols to the ambient $\beta_{\text {ext }}$ could be higher than what is discussed above. However, under the average ambient conditions encountered during FRAPPÉ (average RH $\sim 44 \pm 17 \%$ ), the increase in ambient $\beta_{\text {ext }}$ due to aerosol hygroscopicity is not expected to be significant $(\sim 20 \%)$ given the high organic fraction of 64-74\% in urban, O\&G-, or urban + O\&Ginfluenced plumes (Massoli et al., 2009). In agriculturally influenced plumes, the influence of nitrate aerosol on ambient $\beta_{\text {ext }}$ will be greater because of the lower organic fraction and

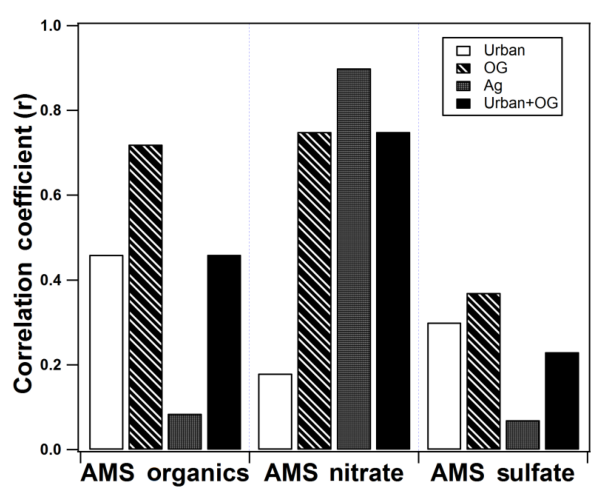

Figure 4. Correlations coefficients of $\beta_{\text {ext }}$ vs. aerosol composition for urban, $\mathrm{O} \& \mathrm{G}$, agriculture, and urban $+\mathrm{O} \& \mathrm{G}$ emissions.

higher nitrate mass in these plumes, re-emphasizing the role of nitrate aerosol in $\beta_{\text {ext }}$ for such emissions.

\subsection{Mass extinction efficiency}

Mass extinction efficiency (MEE) is a function of the diameter of the particle, wavelength of attenuated light, and aerosol refractive index (Seinfeld and Pandis, 2006). To further asses the impacts of aerosol sources on $\beta_{\text {ext }}$, MEE values, i.e., the ratio of the observed $\beta_{\text {ext }}$ to NR-PM 1 mass, in different air masses were estimated. For this analysis, MEE values were determined as the slope of the weighted linear ODR fits of $\beta_{\text {ext }}$ against NR-PM 1 mass, with weights representing standard deviations equal to the uncertainties in NR-PM 1 mass $(30 \%)$ and $\beta_{\text {ext }}(10 \%)$. As indicated in Fig. 5a-d, MEE values under the urban, O\&G, agriculture, and urban + O\&G influence were $\sim 1.51 \pm 0.49 \mathrm{~m}^{2} \mathrm{~g}^{-1}(r=$ $0.40), \quad 1.62 \pm 0.51 \mathrm{~m}^{2} \mathrm{~g}^{-1} \quad(r=0.79), \quad 2.27 \pm 0.83 \mathrm{~m}^{2} \mathrm{~g}^{-1}$ $(r=0.83)$, and $2.14 \pm 0.68 \mathrm{~m}^{2} \mathrm{~g}^{-1}(r=0.73)$, respectively. The highest average MEE value was observed in agricultural plumes although, considering the uncertainties in the fitted slopes, the MEE values were not significantly different. The overall MEE value in the Front Range, i.e., MEE observed for aerosols in all air mass types but in the absence of biomass burning, was $2.24 \pm 0.71 \mathrm{~m}^{2} \mathrm{~g}^{-1}(r=0.80)$. Based on the values of the intercepts of the ODR fits in Fig. 5, it appears that at background levels of NR-PM 1 mass there was a background extinction value of $\sim 2 \mathrm{Mm}^{-1}$ in all, except agricultural, plumes. This observation could be explained by optical extinction due to the presence of refractory aerosol species, such as black carbon or dust, which are not accounted for in NR-PM 1 mass. A high degree of correlation between $\beta_{\text {ext }}$ and $\mathrm{CO}$ (Fig. 2) in urban plumes and low average concentrations of some of the dust components (e.g., calcium and magnesium) throughout the region support the non-negligible contribution of $\mathrm{BC}$ to $\beta_{\text {ext }}$ in the Front Range.

As seen in Fig. S2, different aerosol mass distributions were observed under different air mass types. For the mass distribution analysis, $d_{\mathrm{va}}$ (vacuum aerodynamic diameter) 

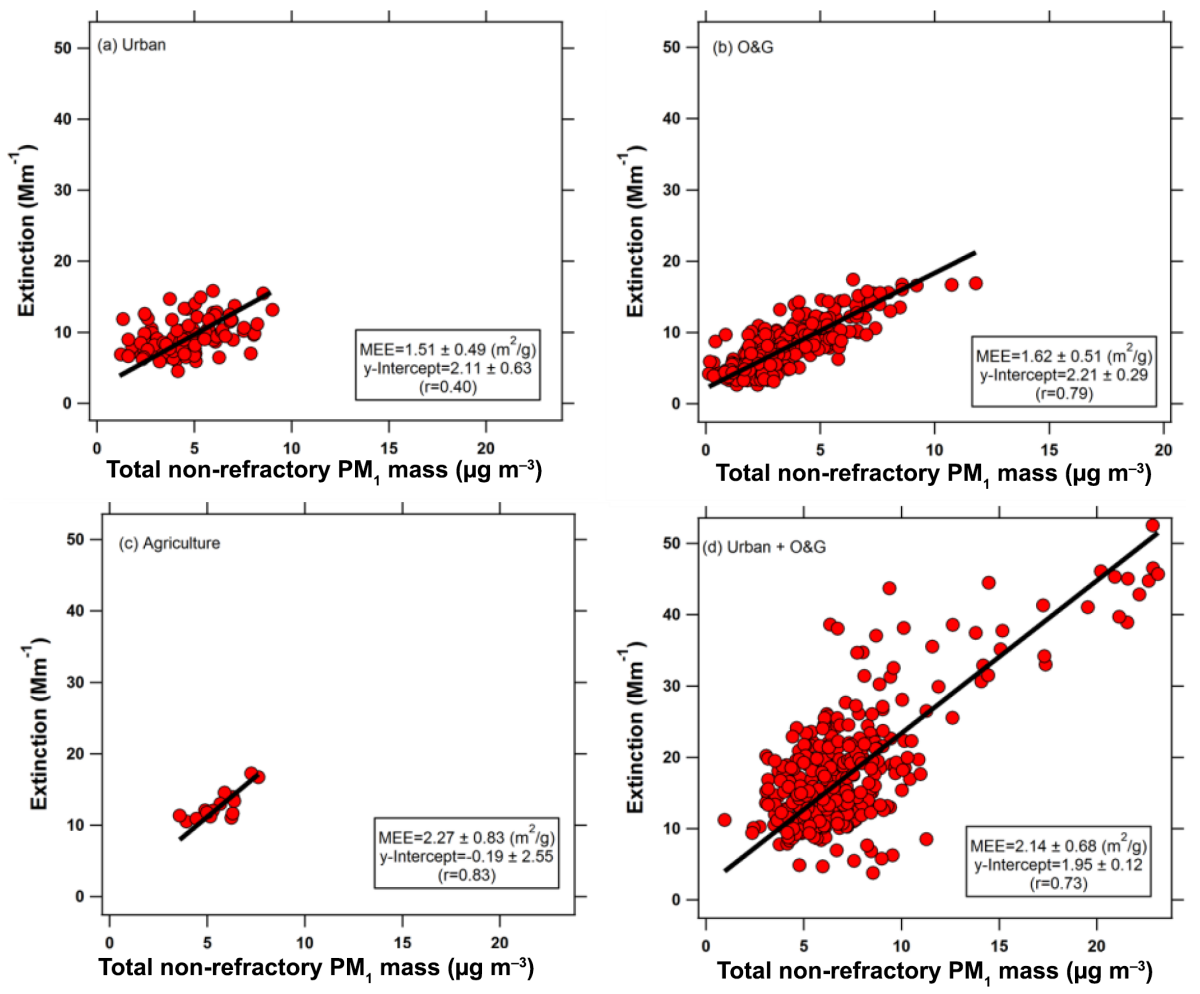

Figure 5. Mass extinction efficiencies (MEEs) under (a) urban, (b) O\&G, (c) agriculture, and (d) urban+O\&G influence.

was converted to $d_{\mathrm{p}}$ (physical diameter) by dividing $d_{\mathrm{va}}$ by the overall mass-weighted effective density $(\rho)$, assuming $\rho=1.25 \mathrm{~g} \mathrm{~cm}^{-3}$ for OA, assuming $\rho=1.75 \mathrm{~g} \mathrm{~cm}^{-3}$ for ammonium sulfate and ammonium nitrate, and assuming that particles sampled by the mAMS were internally mixed (Jayne et al., 2000; Seinfeld and Pandis, 2006). Next we examine the similarity of MEE values observed in the Colorado Front Range to previous measurements. MEE is the sum of the mass absorption and scattering efficiencies (MAE and MSE, respectively), which both depend on particle size, refractive index, and wavelength of light (Seinfeld and Pandis, 2006). For typical urban air masses, mass distributions were dominated by organic aerosols in the size range of $d_{\mathrm{p}}=150-500 \mathrm{~nm}$ (Fig. S2a). This is consistent with previous observations for urban aerosol volume distributions with modes at the size range of $d_{\mathrm{p}} \sim 200-500 \mathrm{~nm}$ (Seinfeld and Pandis, 2006). In O\&G air masses (Fig. S2b), individual mass distributions were broader, with modes for all species shifted to larger sizes $\left(d_{\mathrm{p}} \sim 200-550 \mathrm{~nm}\right)$. In agriculturally influenced air masses nitrate aerosols presented a significant mode in the size range of $d_{\mathrm{p}} \sim 250-400 \mathrm{~nm}$, while OA species were concentrated on smaller sizes $\left(d_{\mathrm{p}} \sim 100\right.$ $200 \mathrm{~nm}$; Fig. S2c). The mass distributions in urban + O\&G plumes were more variable. Occasionally, the distribution was dominated by OA in the smaller size range $(\sim 90$ $110 \mathrm{~nm})$, but it also included contributions from sulfates and nitrates in the larger size range $(\sim 225-275$ and $\sim 430$
$550 \mathrm{~nm}$ ) (Fig. S2d), while other times the mass distribution had significantly higher contribution from OA in the size range of $\sim 225-350 \mathrm{~nm}$, showing a clear shift and OA growth to larger sizes (Fig. S2e).

Keeping in mind that in the presence of absorbing species, MEE is higher than MSE, in the absence of estimates of MEE in other regions we present estimates of MSE from previous studies for comparison with the current MEE estimates in the Front Range. $\mathrm{PM}_{2.5}$ scattering efficiencies at $550 \mathrm{~nm}$ in several ground-based studies at urban commercial/residential sites have typically been measured to be in the range of 2$3 \mathrm{~m}^{2} \mathrm{~g}^{-1}$ (e.g., Chow et al. 2002; Hand and Malm, 2007). In such studies, the main aerosol sources contributing to the observed $\mathrm{PM}_{1}$ MSE were the automotive emissions and combustion processes. Although the contribution of elemental or black carbon to $\mathrm{PM}_{1}$ mass during FRAPPÉ is unknown, similar to these previous studies, OA contributed the most to the NR-PM ${ }_{1}$ mass in the Front Range, and in comparison the observed average MEE value $\left(2.24 \pm 0.71 \mathrm{~m}^{2} \mathrm{~g}^{-1}\right)$ is consistent with the previous estimates of MSE.

\subsection{Impacts of biomass burning emissions on optical extinction}

During 11 and 12 August, several wildfires were observed at Rocky Mountain National Park, near Tonahutu Creek Trail, about $95 \mathrm{~km} \mathrm{NW}$ of Denver and Grand Mesa, Uncompah- 


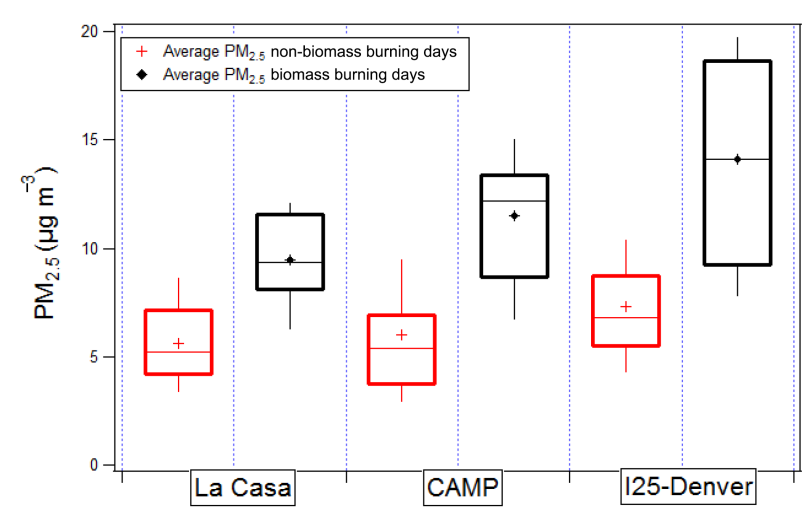

Figure 6. Daily (09:00-19:00 local time) average $\mathrm{PM}_{2.5}$ mass concentration for 3 monitoring sites for (a) non-biomass-burning days of 26, 29, and 31 July and 2, 3, 7, 8, 15, 16, and 18 August and (b) biomass burning days of 11 and 12 August. The whisker top, whisker bottom, box top and box bottom represent the 90th, 10th, 75th, and 25th percentiles, respectively.

gre, and Gunnison National Forest. BB gas-phase markers, namely hydrogen cyanide $(\mathrm{HCN})$ and $\mathrm{CH}_{3} \mathrm{CN}$ from TOGA and PTR-MS airborne data, respectively, were elevated in the boundary layer throughout the flights on 11-12 August compared to non-biomass-burning days (26, 29, and 31 July and 2-3, 7-8, 15-16, and 18 August). For example, during the $\mathrm{BB}$ days, the $\mathrm{HCN}\left(\mathrm{CH}_{3} \mathrm{CN}\right)$ mean mixing ratio in the boundary layer was $516 \pm 58 \mathrm{pptv}(201 \pm 44 \mathrm{pptv})$, whereas the boundary layer mean mixing ratio on non-BB days was $327 \pm 59 \mathrm{pptv}(148 \pm 38 \mathrm{pptv})$. Since elevated levels of HCN and $\mathrm{CH}_{3} \mathrm{CN}$ were not observed in individual plumes but rather throughout the boundary layer on 11-12 August, a regional influence of biomass burning emissions was suspected to be present in the Front Range during this time. In addition, a $25 \mathrm{ppbv}$ increase in $\mathrm{CO}$ background values was observed on 11-12 August (Fig. S3) compared to non-BB days. Ground-based measurements of $\mathrm{PM}_{2.5}$ from DenverLa Casa $\left(39.78^{\circ} \mathrm{N},-105.01^{\circ} \mathrm{W}\right)$, Denver-CAMP $\left(39.75^{\circ} \mathrm{N}\right.$, $\left.-104.99^{\circ} \mathrm{W}\right)$, and Denver-I25 $\left(39.73^{\circ} \mathrm{N},-105.02^{\circ} \mathrm{W}\right)$ sites were analyzed to assess the regional impact of wildfire emissions in the Front Range to $\mathrm{PM}_{2.5}$ during the $\mathrm{BB}$ and nonBB days. The time series of $\mathrm{PM}_{2.5}$ mass concentrations at the sites described above during days preceding and following the wildfires show increases in mass concentration for $\mathrm{PM}_{2.5}$ during the days of $\mathrm{BB}$ (Fig. S4). The mean $\mathrm{PM}_{2.5}$ mass concentrations during 09:00-19:00 local time at Denver, La Casa, Denver-CAMP, and Denver-I25 during non-BB days were $5.61 \pm 2.02,6.01 \pm 3.52$, and $7.28 \pm 2.91 \mu \mathrm{g} \mathrm{m}^{-3}$, while mean mass concentrations increased to $9.47 \pm 2.05$, $11.51 \pm 3.04$, and $14.08 \pm 4.68 \mu \mathrm{g} \mathrm{m}^{-3}$, respectively, during the BB days. As seen in Fig. 6, the average daytime $\mathrm{PM}_{2.5}$ mass concentration on BB days increased by $75-98 \%$ compared to the non-BB days, confirming the regional influence of wildfires on the Front Range aerosol loadings.

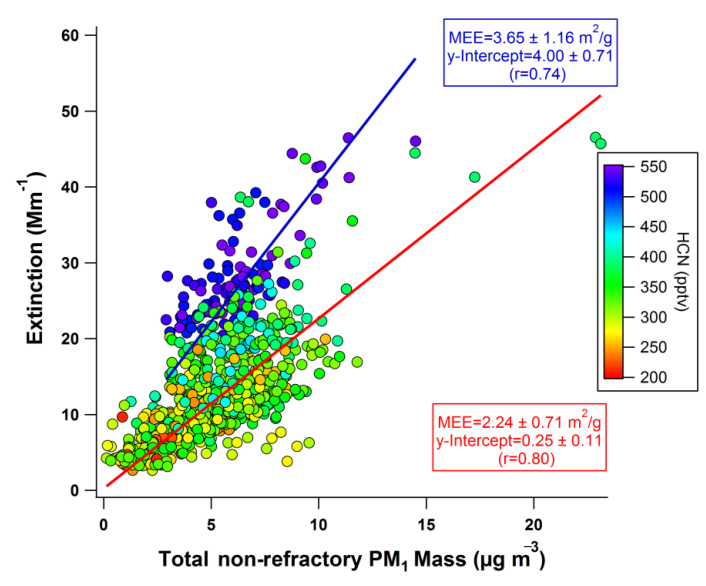

Figure 7. Orthogonal distance linear regression fits to extinction $\left(\mathrm{Mm}^{-1}\right)$ vs. total NR-PM 1 mass $\left(\mu \mathrm{g} \mathrm{m}^{-3}\right)$. Data points are color coded with the average $\mathrm{HCN}$ mixing ratio for non-biomass-burning and biomass burning days.

In addition to scattering of light by smoke particles, $\mathrm{BB}$ emissions of $\mathrm{BC}$ and brown carbon $(\mathrm{BrC})$ can lead to significant absorption of the solar radiation in the visible and $\mathrm{UV}$ region; at $632 \mathrm{~nm}$ absorption by $\mathrm{BrC}$ is minimal (Lack et al., 2012; May et al., 2014). MEE values were analyzed for days with and without the BB influence, using weighted linear ODR fit analysis, as explained previously. As seen in Fig. 7, average MEE on 11-12 August was $\sim 63 \%$ greater compared to days without the influence of BB $\left(3.65 \pm 1.16 \mathrm{~m}^{2} \mathrm{~g}^{-1}\right.$ vs. $\left.2.24 \pm 0.71 \mathrm{~m}^{2} \mathrm{~g}^{-1}\right)$. Additionally, during 11-12 August, the background value of airborne $\beta_{\text {ext }}$ was higher at $4.00 \pm 0.71 \mathrm{Mm}^{-1}$ compared to $0.25 \pm 0.11 \mathrm{Mm}^{-1}$ on days without the BB influence, suggesting the additional contribution to $\beta_{\text {ext }}$ from the wildfires. Although the AMS does not detect refractory materials such as $\mathrm{BC}$ due to the relatively low temperature of its vaporizer $\left(600^{\circ} \mathrm{C}\right)$, it is likely that on $11-12$ August $\mathrm{BC}$ emissions from the fires had resulted in elevated extinction values on a regional scale, resulting in higher MEE. The observed increase in MEE on 11-12 August suggests that regional BB emissions have at least a comparable impact on aerosol optical extinction and visibility in the Front Range relative to the local sources.

\section{Conclusions}

Airborne aerosol optical extinction $(632 \mathrm{~nm})$ and submicron non-refractory aerosol composition were measured during the summer in the Colorado Front Range to understand sources and processes that impact summertime visibility in the area. In assessing the role of atmospheric processing on $\beta_{\text {ext }}$, the $\Delta \beta_{\text {ext }} / \Delta \mathrm{CO}$ enhancement ratio increased in aged urban air masses by $\sim 54 \%$. The increase in $\Delta \beta_{\text {ext }} / \Delta \mathrm{CO}$ in the aged air masses was accompanied by a factor of $\sim 5$ 
increase in $\triangle \mathrm{OA} / \triangle \mathrm{CO}$, indicating that secondary formation of organic aerosols had significant impacts on the evolution of urban $\beta_{\text {ext }}$ in the Front Range. Correlation between $\beta_{\text {ext }}$ and organic, nitrate, and sulfate aerosol mass under urban, O\&G, agriculture, and urban $+\mathrm{O} \& \mathrm{G}$ mixed-source influence was analyzed by linear regression fits. $\beta_{\text {ext }}$ best correlated with organic aerosols in the $\mathrm{O} \& \mathrm{G}$ emissions and best correlated with nitrate aerosols under the $\mathrm{O} \& \mathrm{G}$ and agriculture influences. Correlation with sulfate was poor for all air mass types. Estimated average non-refractory mass extinction efficiency values for different air mass types ranged from $1.51 \pm 0.49$ to $2.27 \pm 0.83 \mathrm{~m}^{2} \mathrm{~g}^{-1}$, with the minimum and maximum average values observed in urban and agriculture air masses, respectively. Finally, aerosol components emitted from wildfires during the days of 11 and 12 August increased $\beta_{\text {ext }}$ background values by $\sim 4 \mathrm{Mm}^{-1}$ and resulted in higher average MEE values by about $63 \%$ compared to non-biomass-burning days, indicating that summertime visibility in the Front Range may equally be impacted by regional wildfires in addition to local sources.

\section{Data availability}

Data used in this analysis may be obtained at http://www-air.larc.nasa.gov/cgi-bin/ArcView/discover-aq. co-2014?C130=1.

\section{The Supplement related to this article is available online at doi:10.5194/acp-16-11207-2016-supplement.}

Acknowledgements. The authors thank Daniel Adams (UCR's CNAS Machine Shop) and technicians at the NCAR Research Aviation Facility for integration of the instruments on the aircraft rack, a smooth aircraft integration process, and support throughout the project; Joshua Schwarz (NOAA-ESRL) for providing us the aircraft inlet system; Ron Cohen and Carly Ebben for providing the TD-LIF data; the Colorado Department of Public Health and Environment for funding and ground-based PM data; and the USDA National Institute of Food and Agriculture, Hatch Project accession no. 233133, for additional funding support.

Edited by: J. Surratt

Reviewed by: two anonymous referees

\section{References}

Apel, E. C., Hornbrook, R. S., Hills, A. J., Blake, N. J., Barth, M. C., Weinheimer, A., Cantrell, C., Rutledge, S. A., Basarab, B., Crawford, J., Diskin, G., Homeyer, C. R., Campos, T., Flocke, F., Fried, A., Blake, D. R., Brune, W., Pollack, I., Peischl, J., Ryerson, T., Wennberg, P. O., Crounse, J. D., Wisthaler, A., Mikoviny, T., Huey, G., Heikes, B., O'Sullivan, D., and Riemer, D. D.: Upper tropospheric ozone production from lightning $\mathrm{NO}_{x}$-impacted convection: Smoke ingestion case study from the DC3 campaign, J. Geophys. Res.-Atmos., 120, 2505-2523, 2015.

Bahreini, R., Ervens, B., Middlebrook, A. M., Warneke, C., de Gouw, J. A., DeCarlo, P. F., Jimenez, J. L., Brock, C. A., Neuman, J. A., Ryerson, T. B., Stark, H., Atlas, E., Brioude, J., Fried, A., Holloway, J. S., Peischl, J., Richter, D., Walega, J., Weibring, P., Wollny, A. G., and Fehsenfeld, F. C.: Organic aerosol formation in urban and industrial plumes near Houston and Dallas, Texas, J. Geophys. Res.-Atmos., 114, D00F16, doi:10.1029/2008jd011493, 2009.

Bohren, C. F. and Huffman, D. R.: Absorption and Scattering of Light by Small Particles, New York, Wiley, 1998.

Borbon, A., Gilman, J. B., Kuster, W. C., Grand, N., Chevaillier, S., Colomb, A., Dolgorouky, C., Gros, V., Lopez, M., Sarda-Esteve, R., Holloway, J., Stutz, J., Petetin, H., McKeen, S., Beekmann, M., Warneke, C., Parrish, D. D., and de Gouw, J. A.: Emission ratios of anthropogenic volatile organic compounds in northern mid-latitude megacities: Observations versus emission inventories in Los Angeles and Paris, J. Geophys. Res.-Atmos., 118, 2041-2057, 2013.

Chow, J. C., Watson, J. G., Lowenthal, D. H., and Richards, L. W.: Comparability between $\mathrm{PM}_{2.5}$ and particle light scattering measurements, Environ. Monit. Assess., 79, 29-45, 2002.

Crook, N. A., Clark, T. L., and Moncrieff, M. W.: THE DENVER CYCLONE .1. GENERATION IN LOW FROUDE-NUMBER FLOW, J. Atmos. Sci., 47, 2725-2742, 1990.

Day, D. A., Wooldridge, P. J., Dillon, M. B., Thornton, J. A., and Cohen, R. C.: A thermal dissociation laser-induced fluorescence instrument for in situ detection of $\mathrm{NO}_{2}$, peroxy nitrates, alkyl nitrates, and $\mathrm{HNO}_{3}$, J. Geophys. Res.-Atmos., 107, ACH 4-1ACH 4-14, doi:10.1029/2001jd000779, 2002.

DeCarlo, P. F., Ulbrich, I. M., Crounse, J., de Foy, B., Dunlea, E. J., Aiken, A. C., Knapp, D., Weinheimer, A. J., Campos, T., Wennberg, P. O., and Jimenez, J. L.: Investigation of the sources and processing of organic aerosol over the Central Mexican Plateau from aircraft measurements during MILAGRO, Atmos. Chem. Phys., 10, 5257-5280, doi:10.5194/acp-10-52572010, 2010.

de Gouw, J. and Warneke, C.: Measurements of volatile organic compounds in the earths atmosphere using proton-transferreaction mass spectrometry, Mass Spectrom. Rev., 26, 223-257, 2007.

Ellis, R. A., Murphy, J. G., Pattey, E., van Haarlem, R., O’Brien, J. M., and Herndon, S. C.: Characterizing a Quantum Cascade Tunable Infrared Laser Differential Absorption Spectrometer (QCTILDAS) for measurements of atmospheric ammonia, Atmos. Meas. Tech., 3, 397-406, doi:10.5194/amt-3-397-2010, 2010.

Ely, D. W., Leary, J. T., and Ross, D. M.: The establishment of the Denver visibility standard. Air And Waste Management Association Annual Meeting, Air And Waste Management Association, 1, 1-17, 1993.

Gerbig, C., Schmitgen, S., Kley, D., Volz-Thomas, A., Dewey, K., and Haaks, D.: An improved fast-response vacuum-UV resonance fluorescence CO instrument, J. Geophys. Res.-Atmos., 104, 1699-1704, 1999.

Gilman, J. B., Lerner, B. M., Kuster, W. C., and de Gouw, J. A.: Source Signature of Volatile Organic Compounds from Oil and Natural Gas Operations in Northeastern Colorado, Environ. Sci. Technol., 47 1297-1305, 2013. 
Groblicki, P. J., Wolff, G. T., and Countess, R. J.: VISIBILITYREDUCING SPECIES IN THE DENVER BROWN CLOUD .1. RELATIONSHIPS BETWEEN EXTINCTION AND CHEMICAL-COMPOSITION, Atmos. Environ., 15, 24732484, 1981.

Hand, J. L. and Malm, W. C.: Review of aerosol mass scattering efficiencies from ground-based measurements since 1990, J. Geophys. Res.-Atmos., 112, D16203, doi:10.1029/2007jd008484, 2007.

Hobbs, P. V.: Introduction to Atmospheric Chemistry: A Companion Text to Basic Physical Chemistry for the Atmospheric Sciences, Cambridge, Cambridge UP, 2000.

Huey, L. G.: Measurement of trace atmospheric species by chemical ionization mass spectrometry: Speciation of reactive nitrogen and future directions, Mass Spectrom. Rev., 26, 166-184, 2007.

Huey, L. G., Dunlea, E. J., Lovejoy, E. R., Hanson, D. R., Norton, R. B., Fehsenfeld, F. C., and Howard, C. J.: Fast time response measurements of $\mathrm{HNO}_{3}$ in air with a chemical ionization mass spectrometer, J. Geophys. Res.-Atmos., 103, 3355-3360, 1998.

Jayne, J. T., Leard, D. C., Zhang, X. F., Davidovits, P., Smith, K. A., Kolb, C. E., and Worsnop, D. R.: Development of an aerosol mass spectrometer for size and composition analysis of submicron particles, Aerosol Sci. Tech., 33, 49-70, 2000.

Karl, T., Apel, E., Hodzic, A., Riemer, D. D., Blake, D. R., and Wiedinmyer, C.: Emissions of volatile organic compounds inferred from airborne flux measurements over a megacity, Atmos. Chem. Phys., 9, 271-285, doi:10.5194/acp-9-271-2009, 2009.

Kleinman, L. I., Daum, P. H., Lee, Y. N., Senum, G. I., Springston, S. R., Wang, J., Berkowitz, C., Hubbe, J., Zaveri, R. A., Brechtel, F. J., Jayne, J., Onasch, T. B., and Worsnop, D.: Aircraft observations of aerosol composition and ageing in New England and Mid-Atlantic States during the summer 2002 New England Air Quality Study field campaign, J. Geophys. Res.-Atmos., 112, D09310, doi:10.1029/2006jd007786, 2007.

Lack, D. A., Langridge, J. M., Bahreini, R., Cappa, C. D., Middlebrook, A. M., and Schwarz, J. P.: Brown carbon and internal mixing in biomass burning particles, P. Natl. Acad. Sci. USA, 109, 14802-14807, 2012.

Langridge, J. M., Richardson, M. S., Lack, D., Law, D., and Murphy, D. M.: Aircraft Instrument for Comprehensive Characterization of Aerosol Optical Properties, Part I: Wavelength-Dependent Optical Extinction and Its Relative Humidity Dependence Measured Using Cavity Ringdown Spectroscopy, Aerosol Sci. Tech., 45, 1305-1318, 2011.

Langridge, J. M., Lack, D., Brock, C. A., Bahreini, R., Middlebrook, A. M., Neuman, J. A., Nowak, J. B., Perring, A. E., Schwarz, J. P., Spackman, J. R., Holloway, J. S., Pollack, I. B., Ryerson, T. B., Roberts, J. M., Warneke, C., de Gouw, J. A., Trainer, M. K., and Murphy, D. M.: Evolution of aerosol properties impacting visibility and direct climate forcing in an ammonia-rich urban environment, J. Geophys. Res.-Atmos., 117, D00V11, doi:10.1029/2011jd017116, 2012.

Levin, E. J. T., Kreidenweis, S. M., McMeeking, G. R., Carrico, C. M., Collett Jr., J. L., and Malm, W. C.: Aerosol physical, chemical and optical properties during the Rocky Mountain Airborne Nitrogen and Sulfur study, Atmos. Environ., 43, 19321939, 2009.
Malm, W. C.: Atmospheric Haze-Its Sources and Effects on Visibility in Rural Areas of the Continental United States, Environ. Monitor. Assess., 12, 203-225, 1989.

Massoli, P., Bates, T. S., Quinn, P. K., Lack, D. A., Baynard, T., Lerner, B. M., Tucker, S. C., Brioude, J., Stohl, A., and Williams, E. J.: Aerosol optical and hygroscopic properties during TexAQS-GoMACCS 2006 and their impact on aerosol direct radiative forcing, J. Geophys. Res.-Atmos., 114, D00F07, doi:10.1029/2008jd011604, 2009.

Massoli, P., Kebabian, P. L., Onasch, T. B., Hills, F. B., and Freedman, A.: Aerosol Light Extinction Measurements by Cavity Attenuated Phase Shift (CAPS) Spectroscopy: Laboratory Validation and Field Deployment of a Compact Aerosol Particle Extinction Monitor, Aerosol Sci. Tech., 44, 428-435, 2010.

May, A. A., McMeeking, G. R., Lee, T., Taylor, J. W., Craven, J. S., Burling, I., Sullivan, A. P., Akagi, S., Collett Jr., J. L., Flynn, M., Coe, H., Urbanski, S. P., Seinfeld, J. H., Yokelson, R. J., and Kreidenweis, S. M.: Aerosol emissions from prescribed fires in the United States: A synthesis of laboratory and aircraft measurements, J. Geophys. Res.-Atmos., 119, 11826-11849, 2014.

Middlebrook, A. M., Bahreini, R., Jimenez, J. L., and Canagaratna, M. R.: Evaluation of Composition-Dependent Collection Efficiencies for the Aerodyne Aerosol Mass Spectrometer using Field Data, Aerosol Sci. Tech., 46, 258-271, 2012.

Neff, W. D.: The Denver Brown Cloud studies from the perspective of model assessment needs and the role of meteorology, J. Air Waste Manage., 47, 269-285, 1997.

Park, R. J., Jacob, D. J., Chin, M., and Martin, R. V.: Sources of carbonaceous aerosols over the United States and implications for natural visibility, J. Geophys. Res.-Atmos., 108, 4355, doi:10.1029/2002jd003190, 2003.

Pétron, G., Karion, A., Sweeney, C., Miller, B. R., Montzka, S. A., Frost, G. J., Trainer, M., Tans, P., Andrews, A., Kofler, J., Helmig, D., Guenther, D., Dlugokencky, E., Lang, P., Newberger, T., Wolter, S., Hall, B., Novelli, P., Brewer, A., Conley, S., Hardesty, M., Banta, R., White, A., Noone, D., Wolfe, D., and Schnell, R.: A New Look at Methane and Nonmethane Hydrocarbon Emissions from Oil and Natural Gas Operations in the Colorado Denver-Julesburg Basin, J. Geophys. Res.-Atmos., 119, 68366852, 2014.

Petzold, A., Onasch, T., Kebabian, P., and Freedman, A.: Intercomparison of a Cavity Attenuated Phase Shift-based extinction monitor (CAPS PMex) with an integrating nephelometer and a filterbased absorption monitor, Atmos. Meas. Tech., 6, 1141-1151, doi:10.5194/amt-6-1141-2013, 2013.

Ramanathan, V., Crutzen, P. J., Kiehl, J. T., and Rosenfeld, D.: Atmosphere - Aerosols, climate, and the hydrological cycle, Science, 294, 2119-2124, 2001.

Reddy, P. J., Barbarick, D. E., and Osterburg, R. D.: DEVELOPMENT OF A STATISTICAL-MODEL FOR FORECASTING EPISODES OF VISIBILITY DEGRADATION IN THE DENVER METROPOLITAN-AREA, J. Appl. Meteorol., 34, 616625, 1995.

Richter, D., Weibring, P., Walega, J. G., Fried, A., Spuler, S. M., and Taubman, M. S.: Compact highly sensitive multi-species airborne mid-IR spectrometer, Appl. Phys. B, 119, 119-131, 2015.

Ridley, B. A. and Grahek, F. E.: A SMALL, LOW FLOW, HIGHSENSITIVITY REACTION VESSEL FOR NO CHEMILUMI- 
NESCENCE DETECTORS, J. Atmos. Ocean. Tech., 7, 307311, 1990.

Rosenberg, P. D., Dean, A. R., Williams, P. I., Dorsey, J. R., Minikin, A., Pickering, M. A., and Petzold, A.: Particle sizing calibration with refractive index correction for light scattering optical particle counters and impacts upon PCASP and CDP data collected during the Fennec campaign, Atmos. Meas. Tech., 5, 1147-1163, doi:10.5194/amt-5-1147-2012, 2012.

Scamehorn, H. L.: High Altitude Energy: A History of Fossil Fuels in Colorado, Boulder, CO, Colorado, University Press of Colorado, 2002.

Schneider, W., Moortgat, G. K., Tyndall, G. S., and Burrows, J. P.: ABSORPTION CROSS-SECTIONS OF $\mathrm{NO}_{2}$ IN THE UV AND VISIBLE REGION (200-700 NM) AT 298-K, J. Photoch. Photobio. A, 40, 195-217, 1987.

Seinfeld, J. H. and Pandis, S. N.: Atmospheric chemistry and physics: from air pollution to climate change, Hoboken, New Jersey, John Wiley and Sons, Inc., 2006.

Slusher, D. L., Huey, L. G., Tanner, D. J., Flocke, F. M., and Roberts, J. M.: A thermal dissociation-chemical ionization mass spectrometry (TD-CIMS) technique for the simultaneous measurement of peroxyacyl nitrates and dinitrogen pentoxide, J. Geophys. Res.-Atmos., 109, D19315, doi:10.1029/2004JD004670, 2004.

Thornton, J. A., Wooldridge, P. J., and Cohen, R. C.: Atmospheric $\mathrm{NO}_{2}$ : In situ laser-induced fluorescence detection at parts per trillion mixing ratios, Anal. Chem., 72, 528-539, 2000.

Vu, K. T., Dingle, J. H., Bahreini, R., Reddy, P. J., Campos, T. L., Diskin, G. S., Fried, A., Herndon, S. C., Hornbrook, R. S., Huey, G., Kaser, L., Montzka, D. D., Nowak, J. B., Richter, D., Roscioli, J. R., Shertz, S., Stell, M., Tanner, D., Tyndall, G., Walega, J., Weibring, P., Weinheimer, A. J., Pfister, G., and Flocke, F.: Impacts of the Denver Cyclone on Regional Air Quality and Aerosol Formation in the Colorado Front Range during FRAPPÉ 2014, Atmos. Chem. Phys. Discuss., doi:10.5194/acp-2016-532, in review, 2016.
Warneke, C., McKeen, S. A., deGouw, J. A., Goldan, P. D., Kuster, W. C., Holloway, J. S., Williams, E. J., Lerner, B. M., Parrish, D. D., Trainer, M., Fehsenfeld, F. C., Kato, S., Atlas, E. L., Baker, A., and Blake, D. R.: Determination of urban volatile organic compound emission ratios and comparison with an emissions database, J. Geophys. Res.-Atmos., 112, D10S47, doi:10.1029/2006JD007930, 2007.

Watson, J. G., Fujita, E., Chow, J. C., Zielinska, B., Richards, L., Neff, W., and Dietrich, D.: Northern Front Range Air Quality Study Final Report, Colorado State University, 1998.

Weber, R. J., Guo, H., Russell, A. G., and Nenes, A.: High aerosol acidity despite declining atmospheric sulfate concentrations over the past 15 years, Nat. Geosci., 9, 282-285, 2016.

Wolff, G. T., Countess, R. J., Groblicki, P. J., Ferman, M. A., Cadle, S. H., and Muhlbaier, J. L.: VISIBILITY-REDUCING SPECIES IN THE DENVER BROWN CLOUD .2. SOURCES AND TEMPORAL PATTERNS, Atmos. Environ., 15, 24852502, 1981.

Ying, Q., Mysliwiec, M., and Kleeman, M. J.: Source apportionment of visibility impairment using a three-dimensional sourceoriented air quality model, Environ. Sci. Technol., 38, 10891101, 2004.

Zheng, W., Flocke, F. M., Tyndall, G. S., Swanson, A., Orlando, J. J., Roberts, J. M., Huey, L. G., and Tanner, D. J.: Characterization of a thermal decomposition chemical ionization mass spectrometer for the measurement of peroxy acyl nitrates (PANs) in the atmosphere, Atmos. Chem. Phys., 11, 6529-6547, doi:10.5194/acp-11-6529-2011, 2011. 